\title{
Foundations, ENGOs, Clean Growth Networks and the Integral State
}

\author{
William K. CARroll \\ NicOlas GraHAM \\ MARK SHAKESPEAR
}

\begin{abstract}
Embraced by a professionalized segment of environmentalism, the "clean growth" project aspires to meet Canada's international climate commitments while supporting robust capital accumulation. This study maps the networks of Canadian clean growth organizations and initiatives, the major Canadian foundations that fund them, and the interlocking web of corporate, state, and civil society elites who influence the governance of those foundations and ENGOs. We identify a tightly-knit configuration of corporate, state, and civil-society actors who occupy the boards that fund and govern clean growth ENGOs. The clean growth project, as ideology and as ENGO practice, comprises an aspect of what Gramsci called the integral state, working to mobilize popular support and technical expertise on the climate issue in ways that reproduce climate (in)action, benefit dominant economic and business interests, and sideline the views of critical, transformative social-justice sectors of Canada's environmental community.
\end{abstract}

Keywords: Clean growth, integral state, climate crisis, foundations, ENGOs, corporate networks, interlocks

\section{INTRODUCTION}

$\mathrm{R}$ ecently, within the multi-organizational field that comprises environmentalism in Canada, a professionalized set of ENGOs has embraced "clean growth". Clean growth exponents aspire to meet the country's international climate commitments while supporting a robust rate of capital accumulation. They propose market-based measures, such 
as carbon taxing or cap-and-trade, or technological improvements like carbon capture and storage, to reduce GHG emissions and move Canada towards post-carbon energy transition (Lee 2020). Clean growth, also known as "green growth" by its supporters (Dale et al. 2016) or "climate capitalism" by its critics (Adkin 2017; Sapinski 2016; Graham 2019), "seeks to redirect investments from fossil energy to renewable energy generation so as to foster an ecological modernization of production and reduce greenhouse gas (GHG) emissions" (Sapinski 2015: 268).

The clean growth project stands in sharp contrast to other Canadian ENGOs pressing for climate justice, energy democracy, reconciliation, and a just transition for workers and communities - e.g., The Leap, Keepers of the Water, Indigenous Climate Justice, and Ecojustice. Instead, clean growth proponents promote an energy transition that will remain fully within the existing capitalist form of our political economy. Indeed, by advocating a gradual shift from fossil fuels to renewables, in a manner that maintains profitability and the concentration of economic power in the hands of a relatively small group of major investors, executives and corporate directors, clean growth appeals to the "leading lights" of business (Sapinski 2016, Graham 2019) .

Still, clean growth has received governmental endorsement and is currently the official policy of Canada's federal government, whose PanCanadian Framework on Clean Growth and Climate Change was announced in 2016, nine days after the same government approved two major pipeline projects (one of which the federal government now owns - Linnitt 2016). As a policy framework initiated by ENGOs within civil society and taken up by the state, clean growth exemplifies an aspect of what Gramsci (1971) called the "integral state", "a dialectical unity of political and civil societies", within which the hegemonic power of the ruling class is widely diffused (Perkins 2011: 559). In what follows, we explore the influence of business and state and third sector foundations on the work of clean growth ENGOs, their role in defining and elaborating the clean growth project, and its diffusion across civil society as an expression of the general interest of Canadians.

A clean growth strategy, however, does not square with the scientific consensus on the scale and time frame for transition beyond carbon. As recent IPCC reports emphasize (United Nations 2018), averting climate breakdown will require far more extensive changes, which arguably run against capitalism's drive to accumulate. In this sense, some critics see clean growth as a new climate denialism, a disjuncture between scientific knowledge and political action. According to Klein and Daub, industry, policy makers and political leaders "assure us that they understand and accept the scientific warnings about climate change - but they are in 
denial about what this scientific reality means for policy and/or continue to block progress in less visible ways" (2016).

This study situates the ideology and practice of clean growth within the network that reaches from Canadian foundations that are major donors, to clean growth ENGOs that receive the funds, to other relevant civil-society, state and capitalist organizations, whose governance boards interlock with those of the foundations or the clean growth ENGOs. In this way, we attempt to locate clean growth within the political field of philanthropic, environmental, corporate and state organization, which comprises a segment of the integral state. Our research questions 1) how clean growth initiatives are embedded within a configuration of facilitative funding and governance relations, and 2) how corporate interests, state bodies and other currents of the environmental movement are positioned in the social organization of this network.

\section{The Integral State and Clean Growth in Canada}

Gramsci's (1971) concept of the "integral state" captures the dialectical unity or interweaving of political society (the state apparatus) with the seemingly separate sphere of civil society (institutions such as schools, the third sector, NGOs, trade unions and business organizations). Within the integral state conception, Gramsci's concern was to understand how consent to relations of rule (hegemony) is just as important as openly coercive state rule (domination). He rejected a view of the state as something that sits above civil society and is involved only in regulation and coercion. Instead, he argued that in practice the state is "a complex of practical and theoretical activities with which the ruling class not only maintains its dominance, but manages to win the active consent of those over whom it rules" (1971: 244). Thus, “...the general notion of the state includes elements that need to be referred back to the notion of civil society $\ldots$ in the sense that one might say that the State $=$ political + civil society, in other words hegemony armoured with coercion" (1971: 263). The integral state, in this view, works to construct consent in civil society to the projects and initiatives of corporate elites. And for Gramsci, "the State does not have and request consent but also "educates" this consent by means of political and syndical associations" (1971: 259).

Maher (2017) provides a particularly insightful conception of the integral state. He highlights the dialectical relation between a state that works to maintain capitalist relations and secure elite interests, and nonstate organizations and agencies that enable the state to define and pursue its objectives, while pursuing their own objectives in part through the 
state. In this way, the integral state both responds to pressure from, and organizes the interests of, other social forces (including capitalist and non-capitalist classes). This relational, dynamic conception accords with Raymond Williams's claim that hegemony

does not just passively exist as a form of dominance. It has continually to be renewed, recreated, defended, and modified. It is also continually resisted, limited, altered, and challenged by pressures not all its own (1977:113).

An integral state analysis becomes more pertinent under neoliberalism, where, as state bodies have retreated from regulation and social programming, civil society organizations such as NGOs have risen in importance, eventuating in what Goldman terms the "neoliberalization of civil society" (2005: 270-271). Here, NGOs and states are integrally linked, as the former fill the void left by a lack of state programming, while the latter can selectively support NGOs whose efforts are compatible with state objectives. Such NGOs may receive substantial funding and other support from the capitalist class, both directly from corporations and through philanthropic foundations (Choudry and Kapoor 2013).

Foundations serve as an important component of the integral state. In capitalist democracies, philanthropy tends to skew toward the interests of the dominant class, whose members (wealthy families and corporations) control the funds, thereby setting the agenda for where and how funds are dispensed. Meanwhile, in marshalling private funds for good works, philanthropy acts as a form of elite legitimation (Roelofs 2015), linking class power with legitimation. Moreover, some researchers have found that the concentration of funding among a few big donors can shape NGO aims and initiatives, especially in the area of environmentalism (Jenkins et al. 2017: 1654). ${ }^{1}$ Often foundation funding is provided with stipulations. Unlike membership donations, it is typically targeted for specific projects, and can be discontinued if conditions are not abided (Jenkins et al. 2017; McCarthy 2004). Interlocking directors between foundations and NGOs are another avenue of foundation influence and can assure compliance while directly participating in NGO decisionmaking (Roelofs 2015). Thus, NGOs and their projects can be realigned to the wishes of major funders, or "channelled" away from diverse ideologies, political positions, goals, or viewpoints, into more homogenous conservative or moderately progressive ones (Berman 1983; Callahan 2018; Dowie 2001; Roelofs 2015). Such processes can be selective or

1. Bosso (2005), in the US context, argues that the environmental movement of the 1960s and 70s would not have gained a foothold without the financial support of foundations. 
transformative. "Channelling" or "cherry picking" through selective funding, may alter the composition of the population of NGOs, but foundation funding can also transform internal practices of NGOs. As Bartley observes, foundation support creates incentives for NGOs "to develop bureaucratic divisions of labor and professional staffs, and fosters dependency on donors and a neglect of grassroots organizing" (2007: 230).

In turn, professionalization and bureaucratization can increase NGO legitimacy and visibility, securing greater funding support (Kallman and Clark 2016). As social movements become institutionalized into NGOs, and NGOs align with state, foundation, and corporate interests, movement autonomy and popular participation can dissipate. In the process, radical goals and strategies disappear from the agenda (Choudry and Kapoor 2013; Kallman and Clark 2016). As staff gravitate toward the mainstream in search of funding and legitimacy, NGOs tend to address symptoms of problems rather than their underlying causes (Collins and Rothe 2020).Our study examines the key corporate actors in the emergent clean growth initiative in Canada, focusing primarily on foundations and the ENGOs they support. Although clean growth takes a reformist, as opposed to a transformative, approach to change, we hasten to add that there is a diversity of NGOs, some of which pursue more radical goals and strategies, even as they are constrained by NGOization and elite influence (Callahan 2018; Carroll and Sapinski 2017; Choudry and Kapoor 2013).

Previous research in Canada has documented the emergence of a clean growth project. In her theorization of competing post-carbon visions in Alberta, Adkin (2017) observed features of climate capitalism in the New Democratic government's post-carbon transition model under Premier Rachel Notley (2015- 2019). Likewise Graham (2019) investigated the Canadian fossil fuel sector's strategic support for an emerging climate-capitalist project. Mapping directorate interlocks between Canada's fossil-fuel sector and climate-capitalist organizations, alongside an analysis of the fossil-fuel sector's investments in both renewable energy and efficiency-enhancing carbon-extractive technologies, his research reveals "signposts" of a strategic orientation some oil and gas firms have taken toward clean growth. Lee (2020) analyzes the emergence of the concept of clean growth in Canada during the lead up to Paris climate conference (COP 21) and its ascendency in Canadian climate policy, including the 2016 Pan-Canadian Framework on Clean Growth and Climate Change. The framework recommends a policy of slow domestic and market-based energy transition, to be funded by expanding capacity for bitumen production and transport in the short to medium term, alongside the taxation of those same resources when used domestically. 
Further research by McCartney (2018) and Gutstein (2018) found clean growth policy frameworks in non-state organizations - both in the private sector and in civil society. For instance, McCartney (2018: 62) identifies a stream of policy-focused reports from the Smart Prosperity Institute (SP), one of the ENGOs in this study, that were used as a basis for the Pan-Canadian Framework. Likewise Gutstein documented the role of think tanks and policy-planning organizations in shaping Canadian climate change policy, including a network of new organizations dedicated to clean growth. He found that these organizations, often funded by foundations established by wealthy capitalists, "act as [financial] gatekeepers against more radical kinds of solutions that might see capitalism itself as the true cause of global warming" (2018: 215-216).

Our analysis adds empirically to this research, and to the broader tradition of power structure research in Canada (cf. Porter 1965; Clement 1975; Brownlee 2005), mapping the network of private foundations and clean growth ENGOs. Is this network a well-integrated complex? Does it receive substantial financial and other support from private foundations? Is the clean growth ENGO network linked to other sectors of society - to the fossil-fuel sector, other fractions of capital, to other currents within the environmental movement? Or is the clean growth complex detached from the interests that dominate Canada's current energy system? Like previous sociological studies of corporate interlocks in Canadian society, we explore how clean growth ENGOs are connected with corporate interests of various kinds, and discuss the likely implications for climate politics in Canada.

\section{МеTHоD}

Our research first identifies the clean growth ENGOs receiving major financial support from Canadian foundations. In fall 2018, we requested Revenue Canada data on the 100 largest foundations in Canada (ranked by the total amounts of their gifts) and the donations each provided in 2017. We received 18,346 records of donations from the 2017 fiscal year totaling $\$ 1.377$ billion, with a mean of $\$ 75,070$ and a median of $\$ 5,128$. We were mainly interested in the largest donations, which may create financial dependence, and thus open up the possibility of influence. Such leverage is not necessarily of a directive kind, but may be tacit, as in the unspoken threat of divestment, were the ENGO to adopt positions sharply at variance with the funder.

We next scoured the list of donations and identified nine clean growth ENGOs (promoting business-friendly agendas particularly regarding the 
climate crisis) and three hub organizations (clean growth ENGOs that receive funds from Canada's foundations and channel them to recipients) receiving donations of at least $\$ 50,000$ from any of the foundations. ${ }^{2}$ Our sample includes 12 ENGOs and 10 foundations, with each of the latter having contributed at least $\$ 50,000$ to at least one of the former in the 2017 fiscal year. We then developed a network analysis mapping two types of relations: donations to ENGOs and interlocking leadership, typically involving directors or executives shared by two organizations (whether foundations, ENGOs, corporate, state or other). Lastly, we supplement these findings with a discussion of funding that these ENGOs receive directly from relevant corporations. Before proceeding to the network analysis, in the next section we provide background on the 22 organizations of interest.

\section{Clean growth ENGOs}

Table 1 sketches the twelve ENGOs in our sample and the donations they received in fiscal 2017 from the foundations in our study. The ENGOS in our sample pursue a range of diverse yet complementary practices that advance and garner support for a corporate-friendly, clean growth environmental project. Three of twelve organizations (Alberta Ecotrust, Clean Economy Fund, and Canadian Environmental Grantmakers Network) are organizational "hubs" that bring together different organizations, pool resources and fund environmental initiatives. They create shared priorities and goals among organizations and/or provide grants and funding for clean-capitalist organizations and projects, but do not themselves conduct extensive research on or propose solutions to environmental problems. Problem solving and solutions are, however, the predominant repertoire of action of six of the organizations (Pollution Probe, Canadian Energy Efficiency Alliance, Natural Step Canada, Clean Energy Canada, Smart Prosperity and Ecofiscal Commission). Additionally, Canadian Energy Efficiency, Smart Prosperity and Clean Energy Canada have explicit mandates to build consensus around clean growth by bringing business leaders, NGOs, political elites, academics and other segments of civil society into dialogue and collaboration. Two

2. Although any cutoff is by nature somewhat arbitrary, $\$ 50,000$ seems reasonable. For instance, one of the most important foundations in this study, Suncor Energy Foundation, states on its website that its board of directors 'reviews all major investments greater than $\$ 50,000$ through four meetings a year. See https://www.suncor.com/en-CA/community-investment/suncorenergy-foundation (access date: August 22, 2019). The Suncor Energy Foundation board clearly sees philanthropic 'investments' of this size as significant enough to merit careful scrutiny. 
organizations, Learning for a Sustainable Future, and Student Energy, are educational initiatives. The former disseminates business-friendly environmental curricula; the latter promotes "energy industry literacy" extending the pedagogy of the integral state to formal education, as these organizations endeavor to make a clean growth approach to climate change "common sense." Meanwhile, MaRS is focused on discovery, innovation and start-ups in the growing clean-tech industrial sector in Canada.

Seven of the twelve ENGOs have been established since 2000 and three since 2010, while Smart Prosperity and Efficiency Canada evolved out of existing organizations, re-branding themselves in 2016 and 2018, respectively. ${ }^{3}$ The recent establishment of several organizations reflects the emergence and evolution of a clean growth project in the context of the deepening climate crisis. Nine organizations are based in eastern Canada, placing them in close proximity to established financial wealth. Four are based in Ottawa, perhaps reflecting a desire to influence federal policy formation.

\section{Foundations}

Foundations are often established as the legacy of successful capital accumulation by a family. For instance, much of the fortune that Hart Massey stockpiled from the profits of Massey-Harris Limited (once the British Empire's largest agricultural equipment manufacturer (Newman 1982: 146)) was funneled into the Massey Foundation, established under control of Hart Massey's descendants in 1918, as Canada's first foundation. More recently, corporations have created their own foundations, as have cities. The foundations featured in this study are family-run, corporate or municipal. Traditionally, major foundations of all three types have tended to support conservationist forms of environmentalism, but much less so the more social-justice oriented wing.

The ten foundations supporting clean growth with large donations in 2017 were established between 1937 and 2002, with the older ones being family foundations (McConnell was the second family foundation estab-

3. Efficiency Canada is a major reorganization and redefinition of the earlier Canadian Energy Efficiency Alliance. Smart Prosperity was founded in 2016 and evolved out of Sustainable Prosperity, a market-based climate solutions think tank and academic research network that began in 2008. Sustainable Prosperity's re-branding as Smart Prosperity also goes beyond a re-naming and includes the launch of its corporate and civil society Leaders Initiative. As McCartney (2018) notes, the re-branding and re-organization in October 2016 coincided with Justin Trudeau's announcement of the federal government's energy transition intentions. 
lished in Canada, after the Massey Foundation) and the younger ones mobilizing corporate capital, as part of the turn to business activism in more recent decades (Carroll 2004). The sole municipal institution, the Calgary Foundation, was established in the early years of the post-World War Two economic boom. Purpleville Foundation, the youngest of the lot, was founded in 2002 by John Robert Evans, a medical researcher who served as University of Toronto's president, the Rockefeller Foundation's first Canadian Chair, CEO of Allelix (Canada's first biotechnology company), founding Chair of the Canadian Foundation for Innovation, and as founder of MaRS discovery district (Macdonald 2015). Purpleville allocates its donations mainly to the University of Toronto. In 2017 they awarded $\$ 700,000$ to MaRS in partnership with University of Toronto. The foundations reflect the locus of established financial wealth in Toronto and Montreal and the importance of Calgary, as a corporate headquarters for much of the Canadian oil and gas industry. The foundations vary in size of total annual donations (see column A in Table 2), in the size of their environmental funding envelopes (column B in Table 2 ), and in how much overall environmental funding is directed at the 12 ENGOs supporting clean growth (column $\mathrm{C}$ in Table 2).

Among the family foundations, Ivey stands out as a supporter of ENGOs, and within that, of clean growth, as $41.6 \%$ of its donations to ENGOs target clean growth organizations in our sample. McConnell's overall funding budget is less skewed toward ENGOs, but $42.0 \%$ of its ENGO funding goes to clean growth initiatives. Echo Foundation devotes nearly half its funds to ENGOs, but only $15.3 \%$ of that goes to clean growth organizations (its 2017 gifts included \$350,000 to Ecojustice Canada). McConnell and Ivey are also ideologically diverse in supporting, alongside clean growth, the more social-justice oriented wing of environmentalism. ${ }^{4}$ Much the same holds for Canadian Donner Foundation, well-known for its support of conservative think tanks (Brownlee 2005). They devote $29.3 \%$ of their ENGO funding to clean growth, but also made a $\$ 149,000$ donation in 2017 to Nova Scotia's Ecology Action Centre, a group with an environmental justice mandate.

The three more institutional funders - Calgary Foundation, Suncor Energy Foundation, RBC Foundation - have large overall budgets with relatively small proportions flowing to ENGOs. However, the two cor-

4. McConnell's \$1,105,000 donation to Evergreen, a Toronto-based ENGO whose mission is 'to enable flourishing cities' (see https://www.evergreen. ca/about/ (access date: August 22, 2019)), and Ivey's \$100,000 donation to Ecojustice, a Vancouver-based ENGO that mounts public-interest law suits in pursuit of environmental justice (see https://www.ecojustice.ca/approach/ (access date: August 22, 2019)), are exemplary. 
porate foundations differ sharply from each other in the extent to which their donations to ENGOs support clean growth. RBC's foundation devotes only $5.3 \%$ of its ENGO-bound donations to the 12 ENGOs in our sample; for the Suncor Energy Foundation that figure is 66.2\%. Both corporations are major supporters of the Canadian oil and gas industry. Suncor is the largest energy corporation in Canada and a leading producer of Alberta's tar sands oil, responsible for much of Canada's disproportional contribution to global warming. $\mathrm{RBC}$ is the financial institution most deeply involved in tar sands, according to Banking on Climate Change (Rainforest Action Network, et al. 2019). However, Toronto-Dominion Bank, whose tar sands financing from 2016-2018 totaled $\$ 13.7$ billion (just $\$ 45$ million less than RBC's) also supports ENGOs through its foundation, TD Friends of the Environment. In fiscal 2017, TD Friends gave a total of $\$ 5.857$ million to Canadian charities, $\$ 1.713$ million of which went to 113 Canadian ENGOs (thus averaging \$15,161 per donation, compared to RBC Foundation's more targeted donations to 77 ENGOs, averaging $\$ 41,953$ per ENGO). TD Friends spreads its gifts around in smaller donations to many conservationist groups (which claimed $84.1 \%$ of its 2017 donations to ENGOs) and did not donate $\$ 50,000+$ to any of the ENGOs in our sample. For this reason, it does not appear here or below in our analysis of strong ties in the clean growth funding network.

\section{Foundation Support for Clean Growth ENGOs}

Figure 1 maps the network of 10 foundations, nine clean growth ENGOs and three "hub" ENGOs that fund other ENGOs, including clean growth initiatives. Suncor Energy and Ivey are the most central foundations in the network. Each made large donations to six of the ENGOs. RBC Foundation, McConnell and Jarislowsky made large donations to three of the ENGOs. The Clean Economy Fund is an especially central node, as it received major donations from six foundations but also funneled donations to two clean growth ENGOs. ${ }^{5}$ The Natural Step and MaRS also

5. Not shown in the sociogram is a major donation Clean Economy Fund made to Efficiency Canada in 2018, established in that year as the successor to Energy Efficiency Alliance. For legibility, the sociogram leaves out the smaller funding relations (less than $\$ 50,000$ in 2017). Similarly, we do not chart the various small donations from foundations outside of the ten leading funders of clean growth ENGOs. In fiscal 2017, eight additional foundations gave 13 donations to the three hub ENGOs, totaling $\$ 115,272$, the largest of which was Metcalf's \$30,000 gift to the Clean Economy Fund. However, the nine clean growth ENGOs received donations only from the ten foundations in our sample, including, as smaller donations, the Calgary Foundation's $\$ 35,000$ 
received major donations from several foundations, with MaRS having taken in very large gifts from Purpleville and McConnell.

The funding network is somewhat bifurcated. This is signaled by the diagonal line in Figure 1 which, on the basis of a Girvan-Newman partition, ${ }^{6}$ bisects the network into two relatively cohesive communities, whereby most of the lines connect members of the same community, and few lines cross from one community to the other.

Community A consists of four foundations that are corporate and/ or based in Calgary, and five ENGOs (including the Calgary-based hub, Alberta Ecotrust) aligned with corporate priorities, but less centrally engaged with clean growth as a focal priority. Community B is made up of six family foundations based in Montreal or Toronto and seven ENGOs based outside of Alberta (including the other two hubs). The four ENGOs that place clean growth at the centre of their missions - Smart Prosperity, Clean Energy Canada, the Ecofiscal Commission and the Energy Efficiency Alliance - are in this community, as is Toronto-based MaRS, which emphasizes technological solutions to ecological challenges.

\section{The Network of Interlocking Governance}

Complementing the network of funding flows is the network of interlocking governance. Sociologists have found that, as corporate directors serve on the boards of multiple large companies, they form "a socially integrated corporate elite" (Sapinski and Carroll 2018: 50), an "organized minority" containing "a high degree of social and political interaction among its members" (Brownlee 2005: 19). The elite network promotes cohesion and unity, enabling economically dominant interests to define and advance their interests effectively. Recent research has identified a "carbon-capital elite" within Canada's corporate elite, whose many interlocks with various civil-society organizations project the power of the fossil-fuel sector into the public sphere (Carroll 2017; Carroll et al. 2018). Below, we map elite interlocks among foundations, clean growth ENGOs and other organizations - whether corporations, civil-society groups (including other ENGOs) or state bodies.

gift to Student Energy, \$12,300 gift to Alberta Ecotrust and a \$11,000 gift to The Natural Step from the McConnell Foundation, as well as $\$ 1,900$ from Suncor's foundation to MaRS.

6. The Girvan-Newman algorithm identifies relatively cohesive communities "in which network nodes are joined together in tightly knit groups, between which there are only looser connections" (p. 7821). It iteratively removes lines of highest 'betweenness', successively partitioning the network into mutually exclusive groups (Girvan and Newman 2002). 
From the Canada Revenue data, we created a file that included all the directors of the foundations and ENGOs supporting clean growth. The starting point was the 10 foundations, 9 clean growth ENGOs and three "hub" donors identified above. We next identified the corporations and other organizations whose boards interlock with any of the 22 and added them to the network. This snowballing method enables us to map how clean growth ENGOs and the foundations that support them are embedded in a larger network. By examining the kinds of organizations comprising that network, we can locate the clean growth project within a broader political-economic field.

The kinds of organizations that participate in the elite network is key. The complete network has 109 organizations and 231 individuals, 113 of whom have two or more organizational affiliations, thus creating interlocks. Our snowballing method augments the number of foundations in the network from 10 to 18 and the number of ENGOs from 12 to 17. But most of the additional organizations in the network come from the corporate world. Fully 45 corporations and six industry associations are interlocked with the 22 core organizations supporting clean growth, as are the boards of six think tanks, nine universities, six state bodies (including two federal, three provincial and one municipal) and two other civil-society organizations.

Figure 2 shows the entire interlock network as a collection of points representing the organizations and lines representing the interlocks among them. ${ }^{7}$ For legibility, we do not show the 113 individuals who actually "carry" the interlocks, through their multiple organizational affiliations, but our account below takes note of the key interlockers. Two foundations are isolates - the nine Jarislowsky Foundation directors and three Echo Foundation directors do not sit on any other boards. All others form a single connected component of 107 organizations (see Figure 2).

The governance boards of foundations are far less central in the network than the leadership of clean growth ENGOs. Foundation boards tend to include members of the controlling families and their associates, rather than corporate directors or other players. However, since the controlling families own great wealth, some foundation boards do interlock with the corporate world. Purpleville's Derek W. Evans, a member of the controlling family, also directs tar sands producer MEG Energy (where he is CEO), mining firm Franco-Nevada, and MaRS, creating interlocks among these organizations. In some cases, foundation boards interlock with the leadership of the ENGOs they support, as in McKinsey's interlock with Smart Prosperity. Ivey's board is notable for its interlocks

7. Like the funding sociogram (Figure 1), this mapping shows the state of play as of 2017. 
with MaRS, Clean Economy Fund and Canadian Environmental Grantmakers. Finally, the two corporate foundations (Suncor's and RBC's) have boards interlocked with the corporate world. Calgary Foundation interlocks with two major fossil-capital firms based in Calgary, through chartered accountant Catherine Best.

The ENGOs (shown as white circles) are positioned in the interlock network in distinctive ways, and it is instructive to examine their social circles. Moving across the sociogram from left to right, the EcoFiscal Commission, which mobilizes economists to research and design market-based climate solutions, interlocks mainly with universities and think tanks. Based at McGill University, its chair Charles Ragan of McGill's Max Bell School of Public Policy, is joined by highly-placed academics from five other universities, including Bev Dahlby and Lindsey Tedds of University of Calgary's School of Public Policy (which previous research has found to be deeply ensconced within the carboncapital elite (Carroll, et al. 2018; Carroll, Graham, and Yunker 2018)) and Nancy Olewiler and Richard Lipsey, economists at SFU. Lipsey is also affiliated with Smart Prosperity, as is Stuart Elgie, a professor of law and economics at University of Ottawa who serves as Smart Prosperity's Executive Chair and directs the Ecofiscal Commission. As Gutstein reports $(2018,185-6)$, climate policy in the province of Alberta under former premier Rachel Notley was guided by the Ecofiscal Commission's pro-carbon pricing research and advocacy.

Merran Smith, Executive Director of Clean Energy Canada, an SFU-based think tank that conducts research and proposes policies to "accelerate Canada's clean energy transition" is a Leader at Smart Prosperity and is also affiliated with SFU as a Fellow at its Centre for Dialogue. Smith co-chaired British Columbia's Climate Solutions and Clean Growth Advisory Council that helped shape the province's current climate action plan (Gutstein 2019). Clean Energy Canada's Policy Director, Dan Woynillowicz, is also affiliated with the Green Economy Alliance - a group of over 100 organizations in Ontario promoting the development of a low carbon economy in Ontario. Apart from Clean Energy Canada and the Ecofiscal Commission, the other ten clean growth ENGOs all show substantial corporate presence in their top governance.

For example, Student Energy, a Calgary-based international ENGO whose programs strive to build "the next generation of energy leaders" "9 with chapters on six Canadian university campuses, includes on its board Rhea Hamilton, Ventures Director at the Oil and Gas Climate Initiative,

8. https://cleanenergycanada.org/about-us/ (access date: July 11, 2019).

9. https://www.studentenergy.org/studentenergy/ (access date: August 22, 2019). 
an organization bankrolled by global carbon majors which supports clean growth innovations to recycle $\mathrm{CO} 2$ and reduce methane and $\mathrm{CO} 2$ emissions. ${ }^{10}$ Student Energy co-founder Janice Tran is an investment associate at Generate Capital, a venture capital company. Student Energy director Mihir Desu is a manager at Strategen, a consulting firm that focuses on decarbonizing the energy grid. Student Energy's Executive Director, Meredith Adler, is also a Leader at Smart Prosperity; board member Julia-Maria Becker is Priority Director at Calgary-based Pembina Institute, while Dan Fripke is Senior Advisor at Alberta's Department of Energy.

The most central ENGO in the network is Smart Prosperity (SP). Like the Ecofiscal Commission and Clean Energy Canada, it is based at a university, namely the University of Ottawa, and functions mainly as a think tank focused on energy transition. It convenes leaders in business, government, academia and broader civil society to "map out a course to a stronger cleaner economy". ${ }^{11}$ Its policy-proposals make the transition to a "clean economy" appealing to many corporations, including fossil fuel firms, by promoting an incremental, market-based approach that prices carbon to incentivize a slow, "stable" energy transition, in close alignment with the Trudeau government's Pan-Canadian Framework (McCartney 2018). Indeed, Smart Prosperity's re-branding in October 2016 coincided with Prime Minister Trudeau's announcement of his government's climate policy program, and Trudeau himself was an enthusiastic guest speaker at the organization's (re)launch (Gutstein, 2018: 207). Smart Prosperity is clearly an important component of the integral state. Its initial funding came from government, and several Smart Prosperity leaders in 2016 were closely connected to Environment Canada and the Trudeau government (Gutstein 2018: 206-9). In fall 2015, the newly elected Trudeau government endorsed the Paris Agreement and promised to tackle global warming. In 2016, it released a major report which set out a national energy strategy embracing clean growth, technological innovation and carbon pricing. Rather than putting in place tough measures to achieve the Paris targets, however, the government reframed global warming as a market opportunity for Canada's clean technology sector.The Big Stall traces the origins of the government's climate change plan back to the energy sector itself - in particular Big Oil. It shows how, in the last fifteen years, Big Oil has infiltrated provincial and federal governments, academia, media and the non-profit sector to sway government and public opinion on the realities of climate change

10. https://oilandgasclimateinitiative.com/ (access date: August 22, 2019).

11. https://www.smartprosperity.ca/about?_ga $=2.86015440 .953871859 .1558646385$ -

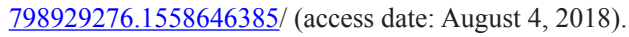


and what needs to be done about it.Working both behind the scenes and in high-profile networks, Canada's energy companies moved the debate away from discussion of the measures required to create a zero-carbon world and towards market-based solutions that will cut carbon dioxide emissions - but not enough to prevent severe climate impacts. This is how Big Oil and think tanks unraveled the Kyoto Protocol, and how Rachel Notley came to deliver the Business Council of Canada's energy plan. Donald Gutstein explains how and why the door has been left wide open for oil companies to determine their own futures in Canada, and to go on drilling new wells, building new oil sands plants and constructing new pipelines. This book offers the background information readers need to challenge politicians claiming they are taking meaningful action on global warming.

SP's leaders interlock primarily with the corporate sector (including Shell Canada and Teck Resources, two of Canada's largest fossil-capital firms, and the Royal Bank of Canada). However, its leadership also overlaps with that of other clean growth ENGOs, as well as with two mainstream conservationist groups (Nature Conservancy and World Wildlife Fund) and two state organizations - Sustainable Development Technology Canada (an Ottawa-based government institute established in 2001) ${ }^{12}$, and the Canada Development Investment Corporation (CDIC). Lorraine Mitchelmore, formerly Regional President of Shell Canada, is SP Co-Chair and a director at CDIC - the federal crown corporation that bought the Trans Mountain Pipeline from KinderMorgan Canada in 2018. (Incidentally, Ian Anderson, former KinderMorgan Canada President and current CEO of Trans Mountain Corporation, is also a director of CDIC). Although clearly tilted toward industry, SP is one of only two clean growth groups whose leadership reaches beyond the corporate, state and ENGO sectors, to include representation from a union (United Steelworkers of America) and a progressive think tank (Broadbent Institute). SP's alignment with the Pan-Canadian Framework and its extensive links into corporate Canada afford it considerable prominence within the emerging clean growth network.

Although MaRS's mandate to commercialize technological innovation by funding tech start-ups extends beyond the clean growth project, the latter is a priority. MaRS leadership overlaps with that of SP via the latter's co-chair, Annette Verschuren, former president of Home Depot Canada, former executive vice-president of CDIC (tasked with privatizing state-owned enterprises) and currently CEO of NStor, an energy storage development company. Long supported by the Ontario government (most notably with a large bailout in 2014 - Marotta 2018), MaRS is now

12.https://www.sdtc.ca/en/about/about-us/ (access date: July 11, 2019). 
funded directly by the federal government (Schwartz 2019). Ontario's Minister of Research and Innovation, John Milloy, served on MaRS's board until the provincial Liberal government lost power in June 2018. Like SP, MaRS's leadership is extensively linked to corporate Canada, through prominent oil executive Derek W. Evans, among others.

Along with representation from three corporations (including carbon giant Teck Resources), Natural Step's leadership interlocks with that of Alberta Ecotrust through David Hughes, CEO of Natural Step Canada and Communications Director at Alberta Ecotrust. As the clean growth network continues to grow, Natural Step Canada, which is part of a global network of organizations under the same brand with a mandate to "accelerate the transition to a sustainable society"13 , is playing a leading role. In 2018, at a G7 meeting, the Circular Economy Leadership Coalition (CELC) was launched under Hughes's co-chairship, as "a national not for profit coalition including corporate and NGO leaders, think tanks, and sustainability experts", with its goal "to eliminate waste and accelerate the reduction of carbon emissions from the Canadian economy" (Smart Prosperity 2018). Also on the CELC board is Mike Wilson, Executive Director of Smart Prosperity.

Consistent with its commitment to bring together major fossil fuel corporations with environmental organizations in supporting ecological initiatives, Alberta Ecotrust's leadership interlocks not only with Natural Step's but with two major Calgary-based fossils, with the city of Calgary (through Holly Gibney, who leads Strategic Business Services for the city), and with the Southern Alberta Land Trust Society. Its website lists, as "visionary corporate partners" four top fossil firms (Cenovus, Imperial Oil, Pembina Pipeline and Suncor) plus petrochemical producer Dow Canada. Although Alberta Ecotrust does not divulge its funders, it is likely that those "visionary partners" rank near the top.

Alberta Ecotrust's Executive Director, Pat Letizia, is also a director of the Clean Economy Fund, a consortium of several Canadian foundations which dispenses grants to accelerate "the shift to a prosperous, low-carbon Canadian economy." ${ }^{14}$ As we saw in Figure 1, the Fund is financed by several foundations. Two of them, Ivey and Donner, are represented on its board, along with Enbridge - Canada's leading pipeline company by volume - and engineering giant AECOM. Eric St-Pierre, Executive Director of the Trottier Foundation, also sits on the Clean

13.https://thenaturalstep.org/ (access date: May 23, 2019).

14. https://mcconnellfoundation.ca/grant/clean-economy-fund// (access date: August 2, 2019). 
Economy Fund board, as does Ersilia Serafini, CEO of Summerhill, a green utilities service firm whose clients include Enbridge. ${ }^{15}$

The third "hub" organization, Canadian Environmental Grantmakers Network, is also a consortium of foundations. On its board are representatives from a dozen foundations (including St-Pierre of Trottier). In this instance, corporate players are in the minority, yet the interlocks are telling. They create direct links to the Canadian Association of Petroleum Producers, Toronto-Dominion Bank's Friends of the Environment foundation and the Royal Bank of Canada. TD and Royal are the top two funders of Canada's tar sands, and rank $8^{\text {th }}$ and $5^{\text {th }}$ respectively among the world's "dirty dozen" worst banks since the 2015 Paris Agreement, according to the 2019 Banking on Climate Change fossil fuel financing report card (p. 8). This is not to say that the CEGN board has been captured by corporate capital - its board does include representation from the Circle on Philanthropy and Aboriginal Peoples in Canada (CPAPC), an Indigenous-led organization whose goal is "to connect with and support the empowerment of First Nations, Inuit and Métis nations, communities, and individuals in building a stronger, healthier future," 16 and from VanCity, a socially-conscious credit union. But the corporate presence suggests that any efforts at progressive, green philanthropy occur within boundaries set by fossil capital and its financial enablers.

Continuing our sweep across the sociogram in Figure 2, the Royal Bank of Canada is also represented in the leadership of Learning for a Sustainable Future, a K-12 pedagogical initiative whose "sustaining partners" (each contributing \$400,000 over 5 years) include Suncor, $\mathrm{RBC}$, and mining transnational Glencore (all represented on the board), as well as the Bank of Montreal, and 3M. Given the organization's focus on school-based programming, it is not surprising that two universities and computer maker Hewlett Packard are also represented in its leadership.

Suncor - Canada's largest fossil firm and as we saw in Figure 1, a major donor (through its foundation) to six of the 12 ENGOs in our core sample - is also directly represented by its corporate leadership on the Pollution Probe board, reinforcing its hefty $\$ 300,000$ donation to Pollution Probe. Pollution Probe, which focuses on research and advocacy work aimed at reducing pollution and carbon emissions, has long been notorious for its close ties to the corporate world, especially the Toronto

15.https://summerhill.com/success-stories/motivating-cold-water-wash-challenge-motivates-apartment-esidents-to-switch-to-cold-water-washes-fortheir-laundry/ (access date: August 19, 2019).

16. http://www.philanthropyandaboriginalpeoples.ca/overview/ (access date: August 19, 2019). 
business community (O'Connor 2014) and exemplifies the corporate capture of ENGOs. ${ }^{17}$ However, Suncor's foundation does not interlock with Pollution Probe, though it does share a director with the Mining Association of Canada, which is represented on Pollution Probe's board, along with the Coal Association of Canada, mining firms Vale and TMAC Resources and corporate law partnership Fasken Martineau.

Finally, Carleton University-based Canadian Energy Efficiency Alliance (CEEA) exemplifies a different phenomenon: it was not captured by industry but was designed as a cross between industry association and think tank. This is reflected in the extensive corporate presence (including Enbridge-controlled Union Gas ${ }^{18}$ ) in its leadership as of 2017. Established in 1995 "to increase competitiveness and environmental protections and improve how stakeholders collaborated to promote energy efficiency in Canada" ${ }^{19}$, CEEA morphed late in 2018 into Efficiency Canada, with stronger ties to Carleton's Engineering and Public Affairs faculties. ${ }^{20}$

\section{Corporate Partners and Funders of Clean Growth ENGOs}

Complementing the funding and governance ties between foundations and clean growth ENGOs are direct relationships of corporate sponsorship. Scouring the websites and annual reports of clean growth ENGOs, we found corporate sponsorships or partnerships involving all but three of the clean growth ENGOs. However, details on the size of corporate donations were generally not given; hence our overview, below, reveals corporate sponsors without specifying funding amounts.

First, Pollution Probe receives donations from a number of sustainability consulting firms and energy corporations, alongside RBC and

17. O'Connor (2014: 125-8) documents the history of Pollution Probe and its close connections with business. While Pollution Probe has maintained a focus on hazardous waste and the effect of pollutants on human health since its inception it increasingly focuses on carbon emissions reduction and climate energy transition policy, with an emphasis on electric and zero-emission vehicles and energy efficiency and conservation. See https://www.pollutionprobe.org/pollution-probe-and-quest-release-new-report-on-energy-policy/ (access date: August 19, 2019).

18. As of 1 January 2019, Union Gas was fully absorbed into Enbridge Gas Inc. See https://www.uniongas.com/about-us/company-overview/we-areenbridge-gas-inc/ (access date: August 19, 2019).

19. https://energyefficiency.org/about-us/mission.html/ (access date: August 2, 2019).

20. https://newsroom.carleton.ca/story/carleton-launches-efficiency-canada/ (access date: July 12, 2019). 
Toyota Canada. The energy corporations include carbon majors Suncor, Enbridge, and Shell Canada, as well as Bullfrog Power (which produces energy from wind, hydro, and biogas, alongside natural gas) and Ontario Power Generation (a provincial crown corporation utilizing hydro, wind, biogas, and nuclear). Bruce Power, a nuclear-power generator located in Ontario, is another funder. ${ }^{21}$

Alberta Ecotrust, the only hub foundation featured in this study funded by both corporations and foundations, receives support from a number of fossil fuel corporations, as well as the government of Alberta. Among the former, Cenovus, Imperial Oil, and ConocoPhillips are "visionary partners", while Keyera, Suncor, Syncrude and ConocoPhillips are listed as "patron partners and major sponsors", alongside bitumen miner Teck Resources, and Capital Power, which generates electricity using natural gas and a range of renewables. ${ }^{22}$

Notable partners of Learning for a Sustainable Future include Pembina - an oil and gas pipeline company - BMO bank, and Glencore ${ }^{23}$, a transnational mining corporation that, in Canada, specializes in coal. Meanwhile, Student Energy lists Royal Dutch Shell ${ }^{24}$ and HSBC bank ${ }^{25}$ as corporate partners. MaRS lists RBC as a founding supporter, CIBC bank and TMX financial services and stock exchange group as major sponsors, and Suncor and Bullfrog Power as minor sponsors. ${ }^{26}$ Natural Step Canada receives funding from Cenovus, Suncor, and TD Bank, alongside Pratt \& Whitney Canada - an aircraft engine manufacturer - and a number of insurance firms.$^{27}$ Corporate funding of Smart Prosperity is derived primarily from a number of francophone economic development agencies - located in Manitoba, Saskatchewan, and Alberta. ${ }^{28}$ The EcoFiscal Commission's corporate funders are Suncor, TD Bank,

21.Pollution Probe. Annual Report: April 2018-May 2019. https://www.pollutionprobe.org/wp-content/uploads/Annual-Report-2018-2019.pdf (access date: January 28, 2020).

22. Alberta Ecotrust. 2017 Annual Report. https://albertaecotrust.com/wp-content/uploads/2018/06/AEF 2017 Annual Report web.pdf (access date: Janaury 28,2020$)$.

23.Learning for a Sustainable Future. 2018 Annual Report. http://1sf-lst.ca/ media/Annual_Reports/AnnualReport_Digital_2018.pdf (access date: January 28,2020 ).

24. Student Energy. 2018 Annual Report. https://student-energy.s3.amazonaws. com/assets/1520/Student $\% 20$ Energy $\% 20$ Annual $\% 20$ Report $\% 202018$.pdf (access date: January 28, 2020).

25.https://www.studentenergy.org/partners/ (access date: January 28, 2020).

26. https://www.marsdd.com/supporters/ (access date: January 28, 2020).

27.http://www.naturalstep.ca/funders/ (access date: January 28, 2020).

28. https://institute.smartprosperity.ca/about/ (access date: January 28, 2020). 
and KTG Public Affairs - a public relations firm. ${ }^{29}$ Lastly, Efficiency Canada, the successor to Canadian Energy Efficiency Alliance, gives pride of place in its listing of allies to Enbridge (as a so-called "GameChanger"), and lists natural gas supplier Fortis BC as a "Champion", along with a number of firms pursuing energy efficiency. ${ }^{30}$

To summarize our findings, the network is highly integrated, both through foundation funding relations involving large sums for clean growth ENGOs and through interlocking leaderships that link clean growth ENGOs to each other, and primarily to the corporate sector. It is interesting that the network of funding relations is to some extent bifurcated between a more transparently corporate segment and a segment of ENGOs with clean growth at the heart of their work, supported by ideologically diverse family foundations. Direct funding of clean growth ENGOs by corporations (many of them major players in the fossil-fuel sector) alongside ENGO-corporate partnerships adds further integration to these networks. Notably, RBC and Suncor fund or partner with some ENGOs in addition to supporting them via foundations (MaRs for RBC, and Alberta Ecotrust, Natural Step, and Pollution Probe for Suncor).

As for elite interlocks, the boards of charitable foundations that fund clean growth ENGOs are only sporadically interlocked with the latter; however, foundations play a channeling role as they are heavily represented on the boards of two key hub ENGOs. Notably, three corporate foundations oriented toward environmental issues are in the network: RBC (both the bank itself and its foundation, with the bank directly represented on three ENGO boards), Suncor Energy Foundation and TD Friends of the Environment. Our snowballing method identifies links to the entire range of civil-society organizations, but as we have seen, ENGOs beyond the ambit of clean growth are essentially absent, while corporate interests are profusely on board the clean growth initiative. Most of the major Canada-based fossil-capital corporations are directly represented in the leadership of the clean growth initiative. Other corporate sectors, including finance, are also represented in clean growth leadership. Leaders of clean growth ENGOs also interlock with each other, further integrating this segment of the integral state. Notably, Smart Prosperity's leadership overlaps with that of four other clean growth ENGOs. Clean growth, now official policy of the federal government, is an elite project well ensconced within structures of corporate and state power, but largely detached from the actual environmental movement.

29. https://ecofiscal.ca/the-commission/the-people-behind-the-commission/\#Funders/ (access date: January 28,2020 ).

30. https://www.efficiencycanada.org/our-allies/ (access date: January 28, 2020). 


\section{Conclusion}

In the context of the deepening climate crisis, a "clean growth" current has emerged within the field of environmental politics, emphasizing that the crisis can be effectively addressed through a series of market-based measures, combined with technological innovations to reduce the carbon intensity of energy systems. In its emphasis on a gradual shift from fossil fuels into renewables, in a manner that maintains profitability and current concentrations of economic power, clean growth is congenial to dominant corporate interests.

The clean growth funding network contains two segments. One consists of foundations that are corporate and/or based in Calgary, and ENGOs that are closely aligned with corporate priorities (often directing their efforts to concerns of legitimation, as in Student Energy) but less centrally engaged with clean growth as a focal priority. The other community is made up of family foundations based in Montreal or Toronto and ENGOs, such as MaRs and Smart Prosperity, that place clean growth at the centre of their missions. As well, the different ENGOs speak to different publics, and employ complementary practices - pedagogical, technological, policy-oriented - in advancing a corporate-friendly environmental project.

Our mapping of the funding network reveals the political reach of foundations, through their conditional and selective support of clean growth as a specific environmental-economic project. Funding operates as a form of allocative power, akin to how financial institutions dispense capital within the corporate economy. Foundations (whether family fortunes or corporate-sponsored funds) mobilize funds skimmed from the accumulation process and distribute them within civil society, shaping the contours and contents of social movements such as environmentalism. Direct funding of clean growth ENGOs from corporations functions in a similar way. Prominent clean growth ENGOs in Canada receive funding from corporations in a range of sectors (including some renewable energy initiatives), but the fossil-fuel sector is a principle sponsor and partner to clean growth ENGOs. This is not surprising given that clean growth projects prioritize reducing emissions intensity of fossil fuel use via technological and market-based means, alongside expanding natural gas industries.

Clearly, Canada's business elite, including the fossil-fuel sector, has thrown considerable support to a clean growth project, and is actively engaged in the governance of clean growth organizations. Just as strikingly, while they interlock with each other's organizations, the leaders of clean growth are detached from prominent Canadian ENGOs critical 
of the fossil fuel industry and the dominant role of corporate power in Canada's energy system. State support for clean growth completes the picture, as governments strive to assuage growing environmental concerns while maintaining the conditions for business-as-usual.

Linked primarily to corporate capital and the state, "clean growth" comprises a parallel universe to the more critical, transformative segment of Canada's environmental movement. The latter is made up of ENGOs like Indigenous Climate Justice, 350.org, David Suzuki Foundation, Ecojustice, Dogwood, and Westcoast Environmental Law - groups that, in contrast to clean growth ENGOs, combine professional staff with copious grassroots supporters in challenging corporate power over ecological matters. Backed by big business (including fossil capital), private foundations and state bodies, clean growth illustrates the power of capital and the state in shaping the meaning of environmentalism and, with that, the policy agenda.

Our analysis demonstrates the analytic value of applying, within a power structure analysis, the concept of integral state, as a dialectical unity of political and civil society where the hegemonic power of corporate capital is widely diffused. It helps reveal how a pro-corporate clean growth project has been initiated and elaborated within civil society and taken up by government. Funded by foundations, hosted in several cases by universities and partly governed by corporate executives, clean growth forms an aspect of the integral state, mobilizing popular support for "climate action" without disturbing business-as-usual. Our findings complement recent research from Graham (2019) on the Canadian fossil fuel sector's strategic support for an emerging climate-capitalist project. Graham's analysis of the fossil-fuel sector's investments in both renewable energy and efficiency-enhancing carbon-extractive technologies reveals "signposts" of a strategic orientation some oil and gas firms have taken toward clean growth. However, he notes that the carbon sector's main priority is efficiency enhancement, not renewable energy technology. Graham concludes that the carbon sector's strategic alignment with "clean growth" is geared towards protecting its vast sunk carbon investments, expanding oil and gas operations in the medium-term while rendering each barrel of oil less "carbon intensive", and transitioning beyond carbon only in the long term.

This approach fits closely with the 2016 Pan-Canadian Framework on Clean Growth, which is buttressed by organizations in the private sector and in civil society, including the stream of policy-focused reports from the Smart Prosperity Institute (McCartney 2018: 62). ${ }^{31}$ Both the

31. More recently, we see an evolution of the Pan-Canadian Framework clean growth agenda in the newly-minted Canadian Institute for Climate Choices, 
Framework and the carbon sector's own strategic alignment with "clean growth" concord closely with Justin Trudeau's declaration in March 2017, to an audience of Houston oil executives, that "no country would find 173 billion barrels of oil in the ground and just leave them there." Trudeau went on to state that "there will come a day, far off, but inevitable at some point, when traditional energy sources will no longer be needed." ${ }^{32}$ Less concordant is the relationship between the "far off" scenarios of clean growth mitigation and the actual process of climate breakdown already in motion, which according to the UN's Intergovernmental Panel on Climate Change, allows humanity only a decade to cut carbon emissions in half. In our view, the scientific consensus on the scale and time frame for shifting beyond carbon requires far more extensive changes, which begin to challenge corporate power, and shift from corporate oligarchy to public, democratic control of economic and ecological decisions.

Our study has several limitations which underscore the need for further research. First, ours is a more architectonic overview of the clean growth network, which would be bolstered by an analysis of discourses, frames and claims of clean growth ENGOs. Second, our research is limited to Canada. Comparative research could reveal wider (global) networks of clean growth organization and advocacy. Third, the snapshot we provide for 2017 could be given longitudinal depth to reveal how the clean growth network has evolved, and how foundation funding may have helped "channel" NGOs towards that project. Finally, the role played by a broader set of neo-liberal think tanks and policy-planning organizations in bolstering a clean growth project could be examined. While such organizations are not exclusively focused on environmental issues, they produce commentary and analysis from a standpoint compatible with business interests, typically denigrating government regulations and advocating market-based solutions to social and envi-

an arms-length think tank established in early 2020 , with funds of up to $\$ 20$ million from the federal government. The Institute consists of three panels, focusing on climate change adaptation, mitigation, and clean growth (Canadian Institute for Climate Choices 2020). Its board of directors includes Dave Collyer, former president of the Canadian Association of Petroleum Producers and of Shell Canada, Christopher Ragan, former chair of the Ecofiscal Commission, and Bruce Lourie, current president of the Ivey Foundation. Underlining the Institute's position as a key node within the integral state, CEO Kathy Bardswick has trumpeted its efforts to create connections with all levels of government - federal, municipal, provincial, territorial, and First Nations (Meyer 2020).

32. See https://www.macleans.ca/economy/justin-trudeaus-speech-in-houstonread-a-full-transcript/ (access date: August 21, 2019). 
ronmental problems (Brownlee 2005; Gutstein 2018). Recent research has documented how think tanks and business associations (along with fossil-fuel industry associations) have shaped Canadian climate change policy (Gutstein 2018), in close communication with fossil capital at the level of governance (Carroll et al. 2018). Such organizations often advocate measures consonant with clean growth, such as greater efficiency in carbon extraction and consumption, new technologies such as carbon capture and storage, and a rate of decarbonization so slow that it amounts to "new denialism" (Klein and Daub 2016).

\section{REFERENCES}

Adkin, Laurie. 2017. Crossroads in Alberta: Climate capitalism or ecological democracy. Socialist Studies/Études Socialistes 12(1):2.

Bartley, Tim. 2007. How foundations shape social movements: The construction of an organizational field and the rise of forest certification. Social Problems 54(3):229-55.

Berman, Edward H. 1983. The Influence of the Carnegie, Ford and Rockefeller Foundations on American Foreign Policy. Albany: State University of New York Press.

Brownlee, Jamie. 2005. Ruling Canada. Halifax: Fernwood Publishing.

Callahan, David. 2018. The Givers: Wealth, Power, and Philanthropy in a New Gilded Age. New York: Vintage Books.

Canadian Institute for Climate Choices. 2020. Charting Our Course: Bringing Clarity to Canada's Climate Policy Choices on the Road to 2050. https:// climatechoices.ca/wp-content/uploads/2020/01/FINAL_Charting-OurCourse.pdf (access date: January 22, 2020).

Carroll, William K. 2004. Corporate Power in a Globalizing World. Toronto: Oxford University Press.

Carroll, William K. 2017. Canada's carbon-capital elite: A tangled web of corporate power. Canadian Journal of Sociology 42:225-60.

Carroll, William K., Nicolas Graham, Michael K. Lang, Zoë Yunker, and Kevin D. McCartney. 2018. The corporate elite and the architecture of climate change denial: A network analysis of carbon capital's reach into civil society. Canadian Review of Sociology/Revue Canadienne de Sociologie 55(3):425-50.

Carroll, William K., Nicolas Graham, and Zoë Yunker. 2018. Carbon capital and corporate influence: Mapping elite networks of corporations, universities, and research institutes. In Corporatizing Canada: Making Business out of Public Service, edited by Jamie Brownlee, Chris Hurl, and Kevin Walby, 58-73. Toronto, Ontario: Between the Lines. 
Carroll, William K., and J.P. Sapinski. 2017. Transnational alternative policy groups in global civil society: Enablers of post-capitalist alternatives or carriers of NGOization? Critical Sociology 43(6):875-92.

Choudry, Aziz, and Dip Kapoor (eds.). 2013. NGOization: Complicity, Contradictions and Prospects. London: Zed Books.

Clement, Wallace. 1975. The Canadian Corporate Elite. Toronto: McClelland \& Stewart.

Collins, Victoria E., and Dawn L. Rothe. 2020. The silent role of non-profit organizations in the neoliberalism trap. In The Violence of Neoliberalism: Crime, Harm and Inequality, 124-37. New York: Routledge.

Dale, Gareth, Manu V. Mathai and Jose A. Puppim de Oliveira (eds.). 2016. Green Growth. London: Zed Books.

Dowie, Mark. 2001. American Foundations: An Investigative History. Cambridge: MIT Press.

Goldman, M. (2005). Imperial Nature: The World Bank and Struggles for Social Justice in theAage of Globalization. New Haven, CT: Yale University Press.

Graham, Nicolas. 2019. Canadian fossil capitalism, corporate strategy, and postcarbon futures. Canadian Review of Sociology/Revue Canadienne de Sociologie 56(2):224-50.

Gramsci, Antonio. 1971. Selections from the Prison Notebooks. New York: International Publishers.

Gutstein, Donald. 2018. Welcome to the clean growth century. In The Big Stall: How Big Oil and Think Tanks are Blocking Action on Climate Change in Canada, 203-19 Toronto: Lorimer.

Gutstein, Donald. 2019. What's the difference between a low-carbon and zero-carbon future? Survival. The Tyee (2 April) https://thetyee.ca/Opinion/2019/04/02/Low-Zero-Carbon-Future-Survival// (access date: April 7, 2019).

Jenkins, J. Craig, Jason T. Carmichael, Robert J. Brulle, and Heather Boughton. 2017. Foundation funding of the environmental movement. American Behavioral Scientist 61(13):1640-57.

Kallman, Meghan E., and Terry N. Clark. 2016. The Third Sector: Community Organizations, NGOs, and Non-Profits. University of Illinois Press.

Klein, Seth, and Shannon Daub. 2016. The new climate denialism: Time for an intervention. Corporate Mapping Project (30 September) https://www. corporatemapping.ca/the-new-climate-denialism-time-for-an-intervention/ (access date: August 8, 2019).

Kohl-Arenas, Erica. 2014. Will the revolution be funded? Resource mobilization and the California Farm Worker Movement. Social Movement Studies 13(4):482-498. 
Lee, Marc. 2020. From clean growth to climate justice. In Regime of Obstruction: How Corporate Power Blocks Energy Democracy, edited by William K. Carroll. Forthcoming at Athabasca University Press.

Linnitt, Carol. 2016. Trudeau approves Kinder Morgan Trans Mountain Pipeline as part of Canada's "Climate Plan". The Narwhal (29 November) https:// thenarwhal.ca/trudeauapproves-kinder-morgan-trans-mountain-pipelinepart-canada-s-climate-plan/ (access date: August 24, 2019).

Macdonald, Cynthia. 2015. John Evans was a champion of innovative medical education. University of Toronto Magazine (17 June) https://magazine. utoronto.ca/people/faculty-staff/john-evans-champion-innovative-medical-education/ (access date: August 22, 2019).

Maher, Stephen. 2017. The capitalist state, corporate political mobilization, and the origins of neoliberalism. Critical Sociology 43(4-5):779-97.

Marotta, Stephanie. 2018. Once bailed out by the government, tech hub MaRS now can't keep up with startups' demand for space. Financial Post (10 July) https://business.financialpost.com/entrepreneur/fp-startups/oncebailed-out-by-the-government-tech-hub-mars-now-cant-keep-up-withstartups-demand-for-space (access date: February 5, 2020).

McCarthy, Deborah. 2004. Environmental justice grantmaking: Elites and activists collaborate to transform philanthropy. Sociological Inquiry 74(2):250-270.

McCartney, Kevin. 2018. Pricing Air to Starve the Fire: An Institutional Ethnography of Smart Prosperity. Thesis, University of Victoria.

Meyer, Carl. 2020. Newly-formed Canadian Institute for Climate Choices calls on Canada to prepare for change. National Observer (21 January) https://www.nationalobserver.com/2020/01/21/news/newly-formedcanadian-institute-climate-choices-calls-canada-prepare-change?utm source $=$ National + Observer\&utm campaign $=b 426 \mathrm{fa} 1 \mathrm{fcb}-$ EMAIL CAMPAIGN 2020 $0122201 \quad 43 \& u t m$ medium $=$ email\&utm term $=0$ cacd0f141f-b426fa1fcb-254390669 (access date: January 22, 2020).

Morrison, Denton E. and Riley E. Dunlap. 1986. Environmentalism and elitism: A conceptual and empirical analysis. Environmental Management 10(5):581-589.

Newman, Peter C. 1982. The Establishment Man: A Portrait of Power. McClelland and Stewart.

O'Connor, Ryan. 2014. The First Green Wave: Pollution Probe and the Origins of Environmental Activism in Ontario. Vancouver, BC: UBC Press.

Perkins, Harold A. 2011. Gramsci in green: Neoliberal hegemony through urban forestry and the potential for a political ecology of praxis. Geoforum 42:558-566.

Porter, John. 1965. The Vertical Mosaic. Toronto: University of Toronto Press. 
Rainforest Action Network (RAN), BankTrack, Indigenous Environmental Network (IEN), Sierra Club, Oil Change International, and Honor the Earth. 2019. Banking on Climate Change: Fossil Fuel Finance Report Card 2019. https://www.ran.org/publications/banking-on-climatechange-2019/ (access date: February 3, 2020).

Roelofs, Joan. 2015. How foundations exercise power. American Journal of Economics and Sociology 74(4):654-675.

Sapinski, J.P. 2015. Climate capitalism and the global corporate elite network. Environmental Sociology 1(4):268-79.

Sapinski, J.P. 2016. Constructing climate capitalism: Corporate power and the global climate policy-planning network. Global Networks 16(1):89-111.

Sapinski, J.P. and William K. Carroll. 2018. Interlocking directorates and corporate networks. In Handbook of the International Political Economy of the Corporation, edited by Andreas Nölke and Christian May, 45-60. Northhampton, MA USA: Elgar.

Schwartz, Zane. 2019. Justin Trudeau announces \$52.4 million over five years for Communitech, MaRS and Invest Ottawa. The Logic (16 April) https:// thelogic.co/briefing/justin-trudeau-announces-52-4-million-over-fiveyears-for-communitech-mars-and-invest-ottawa/ (access date: February $5,2020)$.

Smart Prosperity. 2018. Major business, NGO leaders call for Canada to go wastefree. Global Newswire (20 September) https://www.globenewswire.com/ news-release/2018/09/20/1573572/0/en/Major-business-NGO-leaderscall-for-Canada-to-go-waste-free.html (access date: February 3, 2020).

United Nations. 2018. Global warming report, an "ear-splitting wake-up call" warns UN chief. UN News (8 October) https://news.un.org/en/ story/2018/10/1022492 (access date: February 3, 2020).

Wherry, Aaron. 2020. New federally funded climate institute launches after demise of national roundtable. CBC News (21 January) https://www.cbc. $\underline{\mathrm{ca} / \text { news/politics/canadian-institute-climate-choices-launch-1.5433336 }}$ (access date: January 21, 2020).

Williams, Raymond. 1977. Marxism and Literature. New York: Oxford University Press. 
Table 1. ENGOs pursuing clean growth initiatives

\begin{tabular}{|c|c|c|c|c|}
\hline Nme & $\begin{array}{l}\text { Ye: } \\
\text { Est'd }\end{array}$ & $\begin{array}{l}\text { Head } \\
\text { offine }\end{array}$ & Totnl domgtions & Projext \\
\hline $\begin{array}{l}\text { Pallutin } \\
\text { Probe }\end{array}$ & 1969 & Tritinto & $\$ 446,250$ & 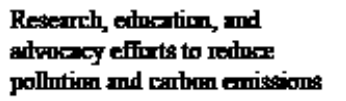 \\
\hline $\begin{array}{l}\text { Alberth } \\
\text { Ecotrust }\end{array}$ & 1991 & Calg̈ry & $\$ 115,140$ & 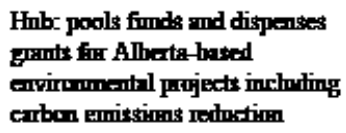 \\
\hline $\begin{array}{l}\text { Leming for a } \\
\text { Sustrimghle } \\
\text { Futme }\end{array}$ & 1991 & Trianto & $\$ 201,900$ & 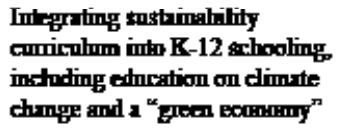 \\
\hline 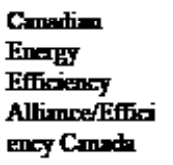 & $\begin{array}{l}1995 f \\
2018\end{array}$ & Othma & $\$ 175,000$ & 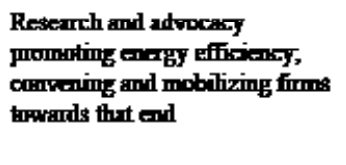 \\
\hline MhRS & 2000 & ; Trarinto & $\$ 1,762,810$ & 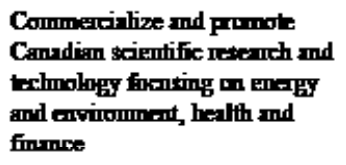 \\
\hline $\begin{array}{l}\text { Gem } \\
\text { Ecanamy Fund }\end{array}$ & 2001 & ; Othme & $\$ 1,216,500$ & 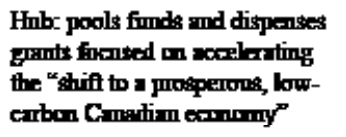 \\
\hline $\begin{array}{l}\text { Nhminl Step } \\
\text { Cimail }\end{array}$ & 2001 & ; Othw & $\$ 827,900$ & 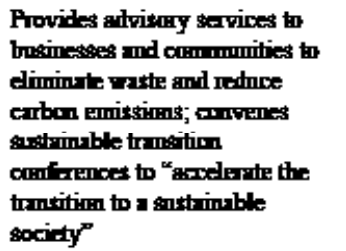 \\
\hline
\end{tabular}


Table 2. Foundations supporting clean growth ENGOs

\begin{tabular}{|c|c|c|c|c|c|c|}
\hline Name & $\begin{array}{l}\text { Year } \\
\text { est'd }\end{array}$ & $\begin{array}{l}\text { Hed } \\
\text { office }\end{array}$ & $\begin{array}{l}\text { A: } \\
\text { Domations } \\
\text { to all } \\
\text { (monities } \\
\text { (f millioms) }\end{array}$ & $\begin{array}{l}\text { B: } \\
\text { Domations } \\
\text { to FiNGOs } \\
\text { (5millions) }\end{array}$ & $\begin{array}{l}\text { C: \% ff B } \\
\text { going to } 12 \\
\text { Clem gowth } \\
\text { ENGOs }\end{array}$ & Type \\
\hline $\begin{array}{l}\text { Machonell } \\
\text { Formintiman }\end{array}$ & 1937 & Mnnfreal & $\$ 16.689$ & $\$ 2.853$ & 42.0 & Family \\
\hline $\begin{array}{l}\text { Foyy } \\
\text { Formintiman }\end{array}$ & 1947 & Tromlt & $\$ 2764$ & $\$ 2,299$ & 41.6 & Family \\
\hline $\begin{array}{l}\text { Drimr } \\
\text { Comital } \\
\text { Fomitimn }\end{array}$ & 1950 & Tromll & $\$ 3231$ & $\$ 0.776$ & 293 & Family \\
\hline $\begin{array}{l}\text { Cilpry } \\
\text { Forundatima }\end{array}$ & 1955 & Colg-y & $\$ 40.518$ & $\$ 0.783$ & 259 & City \\
\hline $\begin{array}{l}\text { C-thy } \\
\text { Forundation }\end{array}$ & 1965 & Colg-y & $\$ 3.433$ & $\$ 0303$ & 293 & Family \\
\hline $\begin{array}{l}\text { Eecho } \\
\text { Fromintimin }\end{array}$ & 1983 & Mnitral & $\$ 6.312$ & $\$ 2.952$ & 153 & Family \\
\hline $\begin{array}{l}\text { Jarisowsty } \\
\text { Formintimin }\end{array}$ & 1991 & Mnntreal & $\$ 8.912$ & $\$ 0290$ & 879 & Family \\
\hline $\begin{array}{l}\text { REC } \\
\text { Fomintime }\end{array}$ & 1992 & Tromltb & $\$ 69.161$ & $\$ 3230$ & 53 & Comporate \\
\hline $\begin{array}{l}\text { Smbrix } \\
\text { Fnofy } \\
\text { Fumitima }\end{array}$ & 1997 & Colgry & $\$ 16,401$ & $\$ 1351$ & 62 & Corporate \\
\hline Pumpleville & 2002 & Trondlo & $\$ 5.887$ & $\$ 0.300$ & 100.0 & Family \\
\hline
\end{tabular}



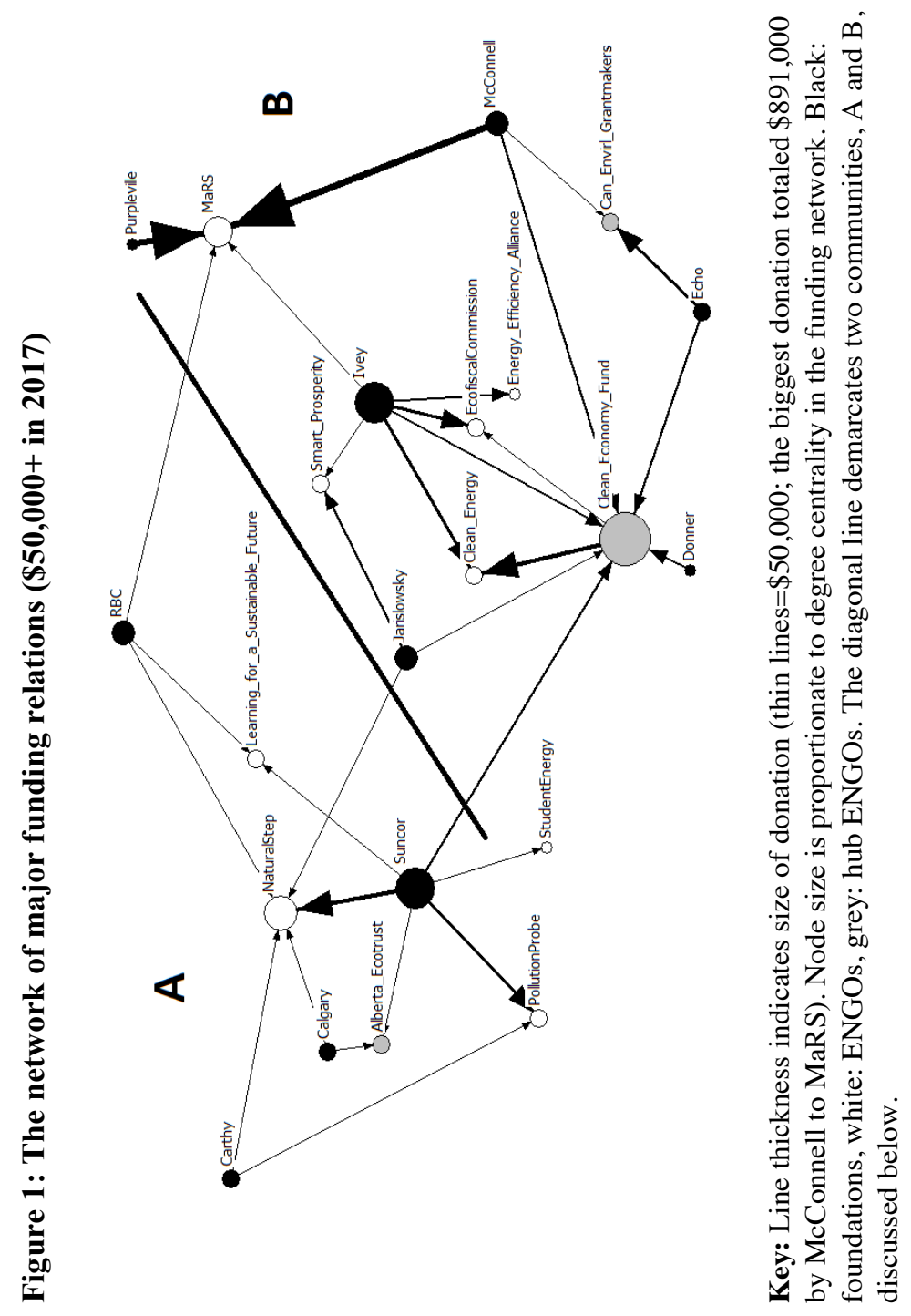

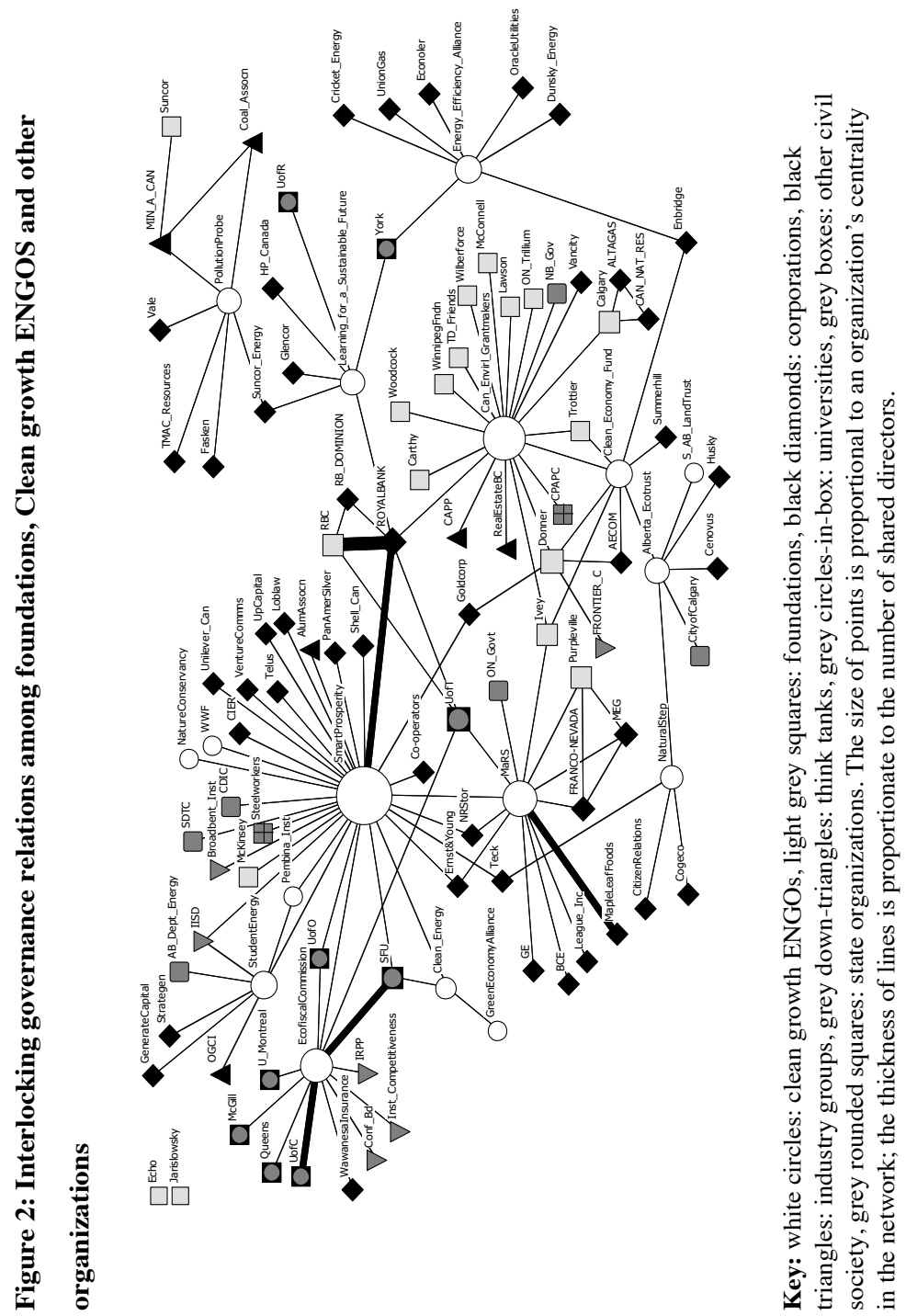
William Carroll teaches Sociology at the University of Victoria. His research interests include the political economy/ecology of corporate capitalism, social movements and social change, and critical social theory and method. He codirects "Mapping the power of the carbon-extractive corporate resource sector," a SSHRC-funded partnership of several universities and civil-society organizations which traces the modalities of corporate power and resistance within the global political economy, focusing on fossil capital based in western Canada.

Email: wcarroll@uvic.ca

Nicolas Graham recently completed his $\mathrm{PhD}$ in the Department of Sociology at the University of Victoria, where he is also a sessional instructor. His previous work in the areas of critical political economy and political ecology has appeared in Canadian Review of Sociology, BC Studies and Capitalism Nature Socialism. $\mathrm{He}$ is currently conducting research on competing political projects for energy transition

Mark Shakespear is an MA candidate in the Department of Sociology at the University of Victoria. His research focuses on the political ecology of climate change and renewable energy transitions, examining projects that enable or obstruct energy democracy. He is presently conducting two other research projects. The first examines avenues of child-nature engagement through outdoor photography. The second explores the use of social practice theories for understanding household sustainability. 
142 (C) Canadian Journal of Sociology/Cahiers canadiens de sociologie 45(2) 2020 